not even as great as that of feldspar, never that of quartz. Popular beliefs are not scientific facts, and it is a scientific fact that nothing but the natural edge of a diamond crystal will cut glass (frequently with very little visible scratching), but everything having the hardness of feldspar will scratch it, as well as glass itself. Popular errors are numerous, and these errors are frequently extensively copied. For instance, a statement appeared some years ago in one of our large magazines that if a precious stone could not be scratched by quartz it would surely be a diamond, and that any jeweller who would object to having a diamond tried with a file should be condemned as a fraud.

Polishing the surface of a precious stone can in no way affect its specific gravity if the stone is properly cleaned, and if the operator has a delicate balance and sufficient experience. In these circumstances it is surprising what exact results the various colors of the various precious stones give us. Further, I may say that, after visiting nearly all the known gem-cutting centres and the chief seats of the manufacture of imitation gems, I have never yet known of an instance where the manufacturer cared the slightest what the specific gravity of his product was, providing it had the desired color, or, if it were to imitate a diamond, it had a greater amount of brilliancy than the material made by one of his most successful competitors. The majority neither know nor care what the specific gravity of the gems is any more than does the regular jeweller.

As regards the optical properties of gems no mention is made of the dichroscope, with the use of which the facetting in no way interferes. The polariscope is also of considerable value. In fact, in the determination of rubies, sapphires, and emeralds, their pronounced optical properties, as shown by the dichroscope, or the polariscope and the spectroscope, together with their specific gravity and their hardness, which is so much greater than that of quartz, will readily distinguish them from everything " imitation." By means of the spectroscope we obtain the red band for the ruby, the absorption bands for the garnet, at $\mathrm{D}, \mathrm{E}$, and $\mathrm{F}$ in the spectrum, or the series of black absorption bands for the zircon. To distinguish glass from a real ruby requires but a glance; to detect the difference between rubies, spinels, garnets, and rubellite is not so easy, and in these cases fusibility is of no value.

I think the experience of those who have given attention to this matter is. first, that the specific gravity of the various precious stones is remarkably constant according to their color, seldom varying more than one in the second place of decimals, and, second, that the hardness of the gem is also remarkably constant, and that lines can be more clearly drawn in cut than in natural crystals, which are frequently not transparent, owing to impurities; namely, placing the sapphire at 9 , the ruby at 8.8 , the aquamarine at 8 , and the emerald at 7.8 .

I should not want to be responsible for the consequences if, at a jeweller's, anyone tried heating a gem in the flame of a spirit lamp or in the flame of a Bunsen burner, any more than I should if a buyer started to try a diamond with a file. Nor should I care to be responsible for the heating in a Bunsen burner of a fine ruby or sapphire, which frequently contains fluid-cavities, or of an emerald, which, if of a fine color, is seldom perfect, owing to internal striæ and fluid-cavities, or the topaz, which is affected by heat, and nearly always contains many minute fluid-cavities. The fusibility of the edges of the gems would not distinguish the artificial rubies of Fremy from those of the true ruby, as both are infusible. Nor would the test of heating in a Bunsen burner be practicable if Mr. Miller were called upon to examine in a few hours from one thousand to fifty thousand gems, and at the same time be perfectly sure that there were no imitation gems in the lot. Such testing needs the experience of the expert, who, before he opens a paper marked " blue or green aquamarine," can tell simply by the weight that the stone in the paper is a blue or green topaz, or who, if the stone is labelled "yellow topaz," can, without looking at it, but simply by the facility with which it slips through the fingers, determine that it is citrine (decolored smoky quartz) or the true mineral topaz; or who, if one hundred stones mounted as rings were placed before him in a tray, without supposing the presence of an imitation stone, could at once detect the single imitation present. Nor would fusibility be of any value in the examination of that class of imitations which are made by dipping heated quartz in green, red, or blue solutions, a common variety of which is known as Mount Blanc, or Alpine ruby.

Finally, few mountings which secure gems are improved by heating them to any extent, and generally the owners do not wish the settings disturbed. As to imitation diamonds there is surely not a jeweller worthy the name who cannot tell a true diamond from a paste one at the first glance, by its adamantine lustre. If it scratches sapphire he may be sure it is a diamond, whereas putting the gem into the flame would not distinguish the diamond from the white topaz or the white zircon or the white sapphire or the white tourmaline or any other white stone that is not fusible.

In conclusion, let me suggest to Mr. Miller the simple test for diamonds, of drawing the stone sharply over a piece of unpainted board in a dark room. Every diamond phosphoresces by friction.

New York, May 11. GEORGE F. KUNZ.

\section{Artificial Production of Variation in Types.}

IN reply to sour request for a few words on the question of artificial production of variations, as presented by Mr. West in Science of A pril 22. I may say that I quite agree with Mr. West in thinking that all attempts to produce new species by mutilations of the parents are foredoomed to failure. The idea that the embryo is in any sense a reflected image of the parent, and consequently that any particular loss or modification of an organ in the parent during adult life must impress itself upon the embryo, has not a shadow of a basis in embryology.

Mr. West asks, "Would it not seem the proper and only method to study the laws governing the modifications of the embryo?" If we substitute germ-cells for "embryo," the question may be answered affirmatively. If the question, as it stands, implies that modifications received during embryonic life, as the result of external influences, would be any more likely to repeat themselves in the next generation than if acquired during adult life, I should say that the assumption is entirely unwarranted.

The form and features of the adult are predetermined in the constitution of the germ-cell. No one denies that external conditions and influences may affect more or less the course of development; but the specific form of the adult is already settled in the germ before development begins. These are mere truisms in embryology,

Clark University, Worcester, Mass.

C. O. Whitman.

\section{The "Hongote" Language.}

IN a series of ten studies of South American Languages, principally from MS. sources, which I published in the last number of the Proceedings of the American Philosophical Society, one was partly devoted to the "Hongote" language, a vocabulary of which I found in a mass of documents in the British Museum stated to relate to Patagonia. I spoke of it as an independent stock, not related to other languages of that locality. In a letter just received from Dr. Franz Boas, he points out to me that this "Hongote" is certainly Salish, and must have been collected in the Straits of Fuca, on the north-west coast. How it came to be in the MSS. referred to, I cannot imagine, but I hasten to announce the correction as promptly as possible.

Philadelphia, May 4.

D. G. Brinton, M.D.

\section{AMONG THE PUBLISHERS.}

THE number of the American Journal of Psychology which is about to appear will contain an article on the variations of the knee-jerk by Dr. Noy es, which contains the results of experiments on a case of dementia. Mr. Bolton contributes a digest of the experiments on memory made by Dr. Boas in the Worcester schools. Mr. Fraser shows the psychological origin of the naive realism of the unthinking man and of the philosophic realism of the Scottish school; both are due to a postulate of the sensations of touch as the ultimate realities. The old philosophers have before this 